\title{
PLASMA RELAXIN IMMUNOACTIVITY DURING THE OESTROUS CYCLE OF THE EWE
}

\author{
WAYNE A. CHAMLEY, T. STELMASIAK* AND \\ GILLIAN D. BRYANT* \\ Reproduction Research Section, S. S. Cameron Laboratory, Werribee, Victoria, \\ Australia, and \\ *Department of Anatomy and Reproductive Biology, School of Medicine, \\ University of Hawaii, Honolulu, Hawaii 96822, U.S.A.
}

(Received 1st February 1975)

\begin{abstract}
Summary. Plasma relaxin immunoactivity was measured every $2 \mathrm{hr}$ during 4-day periods in a series of sheep to cover the 17-day period of the ovine oestrous cycle. The immunoactivity fluctuated considerably throughout each 4-day period, and a large between-animal variation was found. A marked episodic release, occurring at approximately 12.00 and 24.00 hours, was identified and shown to occur more regularly either at certain times of the cycle or in certain animals. Relaxin immunoactivity was high throughout the late pro-oestrous phase of the cycle (Days 15 and 16), and at $24 \mathrm{hr}$ after the onset of the LH peak, coincident with the approximate time when ovulation occurs. Bursts of relaxin activity were found on Days 8 to 9 in one ewe, and Days 10 to 11 and 13 to 14 in another. There was no significant correlation between prolactin levels and relaxin immunoactivity in one ewe studied throughout the oestrous period.
\end{abstract}

\section{INTRODUCTION}

The lack of a radioimmunoassay for plasma relaxin and the difficulties of the available bioassays have until now excluded relaxin from any discussion of reproductive processes with the possible exception of pregnancy. It has been shown that sheep plasma cross-reacted completely in the porcine relaxin (NIH-R-P1) anti-porcine relaxin radioimmunoassay system (Bryant, 1972; Bryant \& Stelmasiak, 1975). A detailed study of relaxin-like immunoactivity in plasma during the sheep oestrous cycle was therefore undertaken in order to correlate any changes in levels with the well described changes in oestrogen, progesterone, LH, FSH and prostaglandin $\mathrm{F}_{2 \alpha}$ (Goding et al., 1973; Salamonsen et al., 1973), and prolactin (Cumming et al., 1972) in an attempt to define possible function(s) of relaxin in the cyclic animal.

\section{Radioimmunoassays}

\section{MATERIALS AND METHODS}

The LH and prolactin assays were performed at the S. S. Cameron Laboratory, Werribee, Australia, and the relaxin assays were done at the University of 
Hawaii, Honolulu, Hawaii. Aliquots of the samples were taken for the respective assays and were transported on solid dry ice and kept frozen until assayed. There is no deterioration of relaxin immunoactivity with time when storage is at $-12^{\circ} \mathrm{C}$ (G. D. Bryant, unpublished).

Relaxin. The technique of Bryant (1972) was used exactly as described, except that separation of bound and free hormone was effected by a conventional double-antibody procedure (Bryant \& Stelmasiak, 1975). Levels are expressed as ng porcine relaxin (NIH-R-Pl)/ml, since the relaxin-like immunoactivity of sheep plasma paralleled that of the standard. The sensitivity of the assay is $>6.3 \mathrm{ng}$ relaxin $/ \mathrm{ml}$ plasma, with a maximum percentage error $(P=0.05)$ of $\pm 50 \%$ when estimates at three concentrations are performed (Bryant \& Stelmasiak, 1975).

$L H$. Levels of $\mathrm{LH}$ were measured by solid-phase radioimmunoassay (Goding et al., 1969). The sensitivity of the assay was $>1.5 \mathrm{ng} / \mathrm{ml}$ plasma; within-assay variation was $\pm 10 \%$ and between-assay variation was $\pm 20 \%$.

Prolactin. Prolactin was measured by solid-phase radioimmunoassay (Fell et al., 1972). The sensitivity of the assay was $>2.1 \mathrm{ng} / \mathrm{ml}$ plasma; and the within-assay variation for samples of 10 to $40 \mathrm{ng} / \mathrm{ml}$ was $\pm 10 \%$ and for samples $>120 \mathrm{ng} / \mathrm{ml}$ was $\pm 30 \%$. The between-assay variation for samples between 2 to $100 \mathrm{ng} / \mathrm{ml}$ was \pm 16 to $30 \%$.

\section{Design of experiment and collection of plasma}

Relaxin and prolactin were measured in plasma samples which had been collected as part of another experiment to examine the secretory pattern of FSH and LH throughout the ovine oestrous cycle (Salamonsen et al., 1973).

Experimental animals. Merino ewes were selected from a flock which was running with a vasectomized ram fitted with a 'Siresine' harness (Radford et al., 1960). The flock was checked daily for oestrus and, for each animal, the stage of the oestrous cycle was calculated from the recorded date of the previous teaser marking. During the experiment, the animals were penned individually in an enclosed shed. They had access to feed and water at all times and were kept under continuous lighting.

Blood samples. On the day before commencement of the experiment, one jugular vein of each animal was cannulated with silastic tubing (Dow Corning). Blood samples $(10 \mathrm{ml})$ were drawn from the jugular vein catheter at $2-\mathrm{hr}$ intervals with all animals being bled at the same time. The period of sampling for each animal did not extend for more than $96 \mathrm{hr}$. After collection, blood samples were immediately centrifuged and the plasma separated and stored at $-12^{\circ} \mathrm{C}$ until assay.

Samples in which relaxin was measured (seven individual sheep), were selected so that they represented plasma samples collected throughout the 17 days of the ovine oestrous cycle. In the sheep which were bled at about the expected time of oestrus (Ewes 7, 6 and 15), the timing of the preovulatory LH surge (Text-fig. 1) was obtained from the data published by Salamonsen et al. (1973).

At the end of the bleeding schedule, each animal was subjected to laparo- 


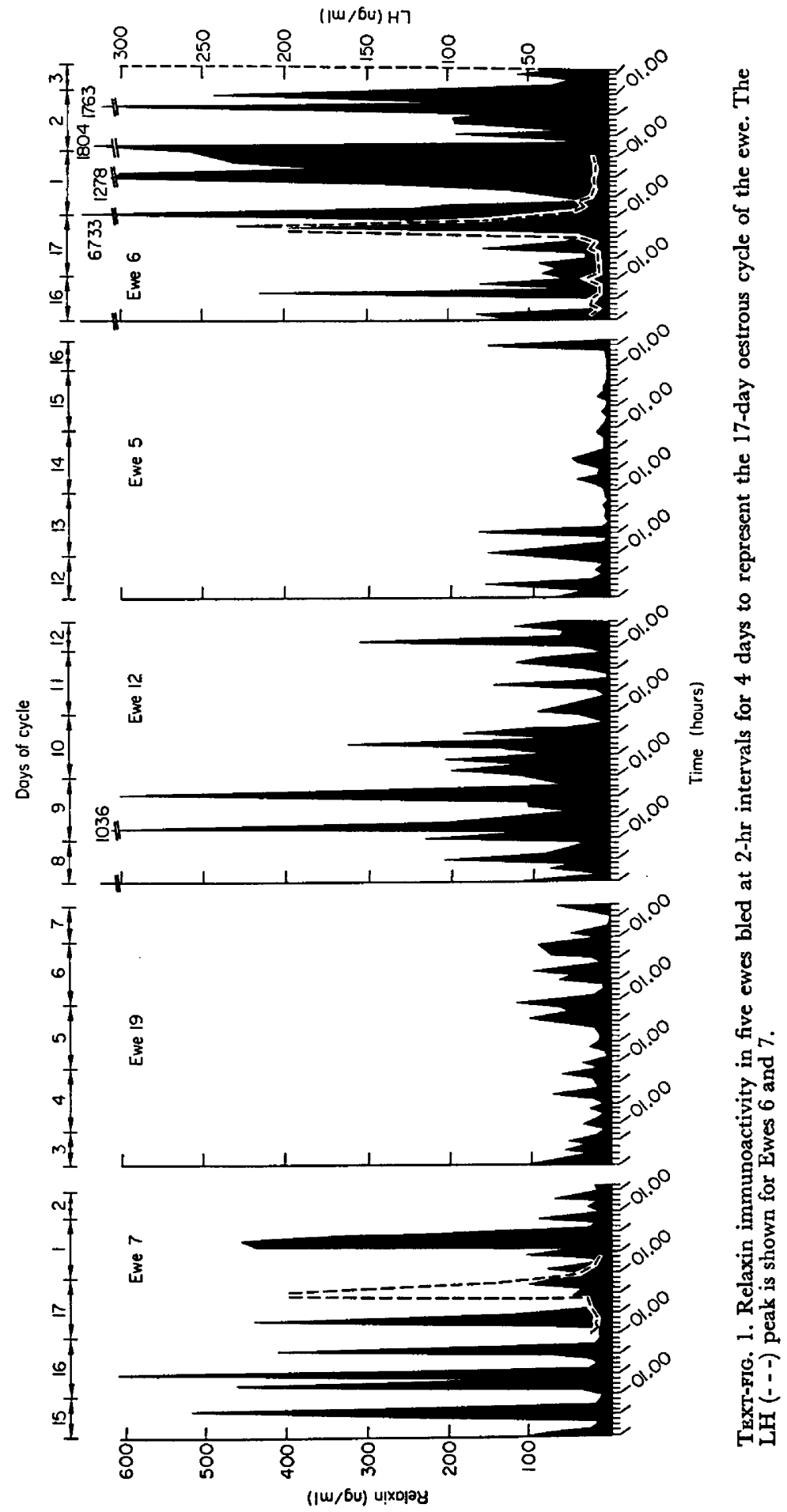


tomy, for examination of the morphology of the ovaries and identification of ewes which had ovulated during the experiment.

\section{RESULTS}

The relaxin levels during a composite oestrous cycle derived from samples from five of the ewes in the experiment are shown in Text-fig. 1. Two additional animals which were bled at periods overlapping those shown in Text-fig. 1 are shown separately in Text-figs 2(a) and 2(b).

Relaxin immunoactivity was depressed during the period of the LH surge in Ewe 7, but not in Ewe 6 (Text-fig. 1). Relaxin concentrations rose at approximately $24 \mathrm{hr}$ after the onset of the LH peak, coincident with the approximate time of ovulation, in Ewes 6 and 7 (Text-fig. 1), but Ewe 15 (Text-fig. 2a) did not show such a dramatic rise at this time, but rather a marked episodic pattern of release, increasing in amplitude from the start of the bleeding schedule. A striking feature of the relaxin measurements shown by most of the animals appears to be the episodic mode of release at approximately 12.00 and 24.00 hours. On several occasions, incremental changes of 600 to $3000 \mathrm{ng} / \mathrm{ml}$ were observed during periods of 2 to $4 \mathrm{hr}$ (Text-fig. 2). The decay of the endogenous immunoactivity was rapid and was consistent with a half-life of approximately 8 min (Bryant \& Stelmasiak, 1975). Marked episodic release of immunoreactive relaxin, with each burst approximately equal in magnitude, was seen in Ewes 6 and 7 (Text-fig. 1) which were both in late pro-oestrus. Large peaks of relaxin immunoactivity were detected at mid-cycle, Days 8 to 9 in Ewe 12 (Text-fig. 1) and Days 10 to 11 and 13 to 14 in Ewe 9 (Text-fig. 2b). The levels of relaxin immunoactivity in Ewes 19 and 5, bled before and after the mid-cycle period respectively, were in general low. The correlation between the levels of relaxin and prolactin in Ewe 15 (Text-fig. 2a) was statistically not significant $(P>0 \cdot 1)$, either as individual values or as means of six samples representing a 12-hr period.

The observations at laparotomy confirmed that new ovulations had occurred in Ewes 6 and 7. All other animals had at least one CL while the two ewes which were bled around mid-cycle (Nos 12 and 9) had the largest numbers of largesized follicles.

\section{DISCUSSION}

Investigations in sheep have established that the ovary and the uterus are sources of immunoreactive relaxin (Bryant et al., 1973; Bryant \& Stelmasiak, 1975), indistinguishable by radioimmunoassay, and that follicles cultured at different stages of the cycle are capable of secreting relaxin in some quantity (R. F. Seamark \& G. D. Bryant, unpublished observation). Histochemical studies in the pig have indicated that the CL is a rich source of relaxin (Belt et al., 1971). The total relaxin immunoactivity measured in the present study may have originated therefore at any given time from the follicle, the CL or the uterus, or from any combination thereof.

The occurrence of elevated relaxin levels shortly after the preovulatory $\mathrm{LH}$ release and at about the time of ovulation warrants further study of this period. 


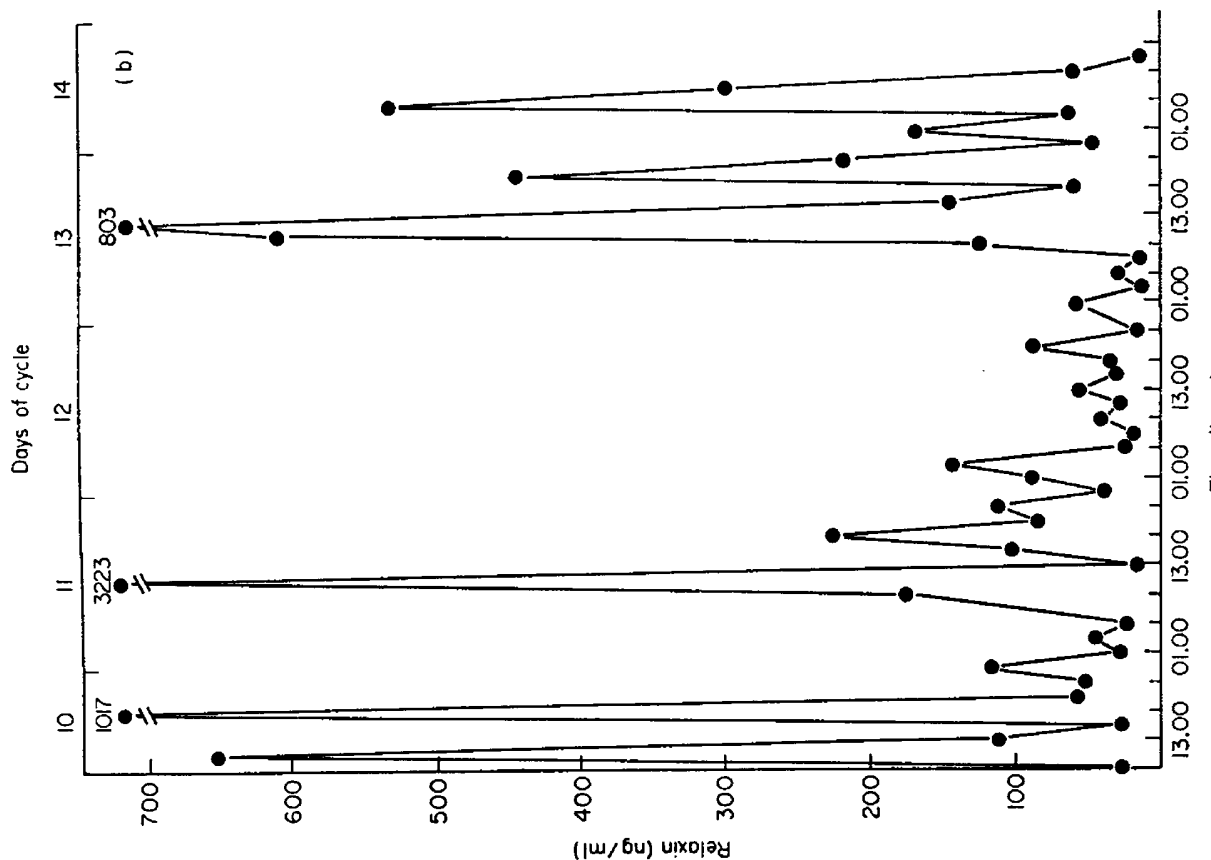

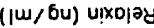

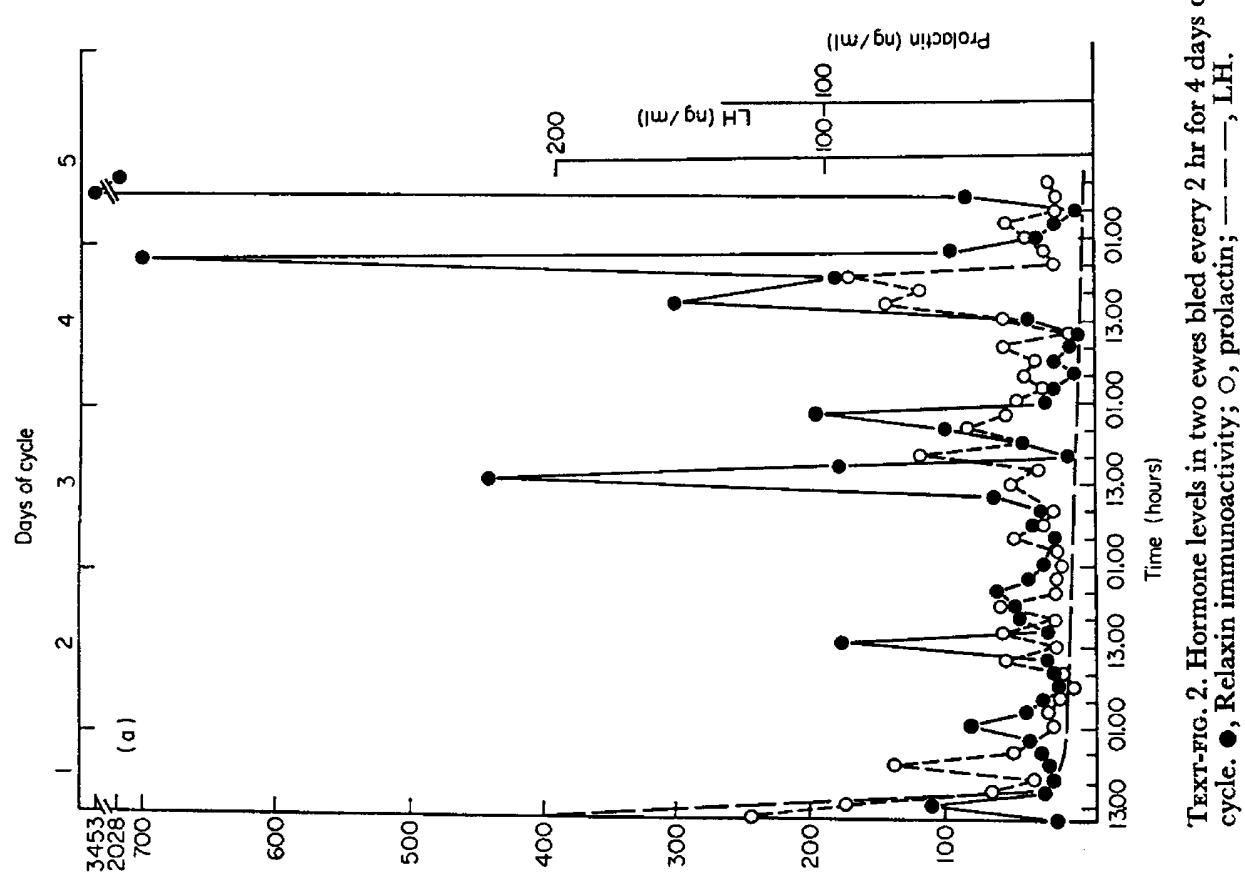

$(\mu \omega / 6 u)$ u!xo|y

D 
Perl \& Gatchpole (1950) have shown that relaxin causes the breakdown of collagenous tissue in the symphysis pubis of the guinea-pig. Chihal \& Espey (1973) have reported that similar changes are seen in the ovary during breakdown of the follicular membrane at the time of ovulation in the guinea-pig. The possibility that relaxin might be involved in the ovulatory process in the sheep seems worthy of close investigation.

There appears little doubt that the relaxin is secreted episodically, but whether this is a true diurnal release awaits further study; such variations were more evident at some stages of the cycle than at others. From the results shown, it is apparent that there is a large between-animal variation in the secretion of immunoreactive relaxin in ewes at the same apparent physiological state, but the ideal sampling time of every $30 \mathrm{~min}$ in one sheep for 17 days is not practical. Even steroid hormones, considered once to be secreted at fairly constant levels, have been found to fluctuate quite dramatically throughout a 24-hr period (Thorneycroft et al., 1974). A peptide hormone with a short half-life (Bryant \& Stelmasiak, 1975) represents an even more difficult problem for study.

There is no evidence that relaxin was influenced by experimental trauma during the collection of blood samples. Conversely, it has been shown that prolactin secretion was markedly influenced by the trauma occasioned by a blocked catheter (Cumming et al., 1972). Since there was no correlation between the elevations in prolactin and relaxin, it is unlikely that relaxin was released in response to stress. However, the injection of ovine prolactin into a ewe experiencing normal cycles caused a rapid rise in relaxin levels (G. D. Bryant, unpublished observation), and a rise in relaxin immunoactivity was shown to follow the rise in prolactin initiated by breast feeding in women (Bryant, 1973). Hence there appears to be a relationship between relaxin and prolactin that is not mediated by stress.

Plasma progesterone levels throughout the ovine oestrous cycle have been reported by several investigators (Thorburn et al., 1969; Bindon, 1971; McNatty et al., 1973). McNatty et al. (1973) described a transient fall in circulating progesterone at about mid-cycle, a time corresponding to one when plasma relaxin activity (in the present study), and cytochrome P-450 activity in sheep CL (Simpson et al., 1973) are high. Relaxin levels were also high at late pro-oestrus when progesterone levels are declining (Thorburn et al., 1969; McNatty et al., 1973).

From the present study it is not possible to define a role for relaxin(s) in the sheep oestrous cycle. Further work is needed for the development of separate assays for the ovarian and uterine relaxins respectively and the application of these to optimally designed experiments for a hormone with a very short halflife in plasma.

\section{ACKNOWLEDGMENTS}

We wish to acknowledge the help given by staff of the Reproduction Research Section during collection of the sheep plasma samples. The help of Dr I. A. Gumming in carrying out the laparotomies is also gratefully acknowledged. We thank Mrs Nam Soon Joun for valuable technical assistance with the relaxin assays. 
One of us (G.D.B.) was supported by a Research Career Development Award HD 70516, T.S. by an International Atomic Agency Fellowship, and W.A.G. by the Australian Wool Council. The relaxin assays were supported by grant no. HD 06633, a Ford Foundation grant 66202 and the Cancer Center of Hawaii CA 15655.

\section{REFERENCES}

Belt, W.D., Anderson, L.L., Gavazos, L.F. \& Melampy, R.M. (1971) Cytoplasmic granules and relaxin levels in porcine corpora lutea. Endoctinology $89,1-10$.

Bindon, B.M. (1971) The role of progesterone in implantation in the sheep. Aust. F. biol. Sci. 24, 149158.

BRYANT, G.D. (1972) The detection of relaxin in porcine, ovine and human plasma by radioimmunoassay. Endocrinology 91, 1113-1117.

Bryant, G.D. (1973) Discussion. In Current Radioimmunoassays for Human Prolactin: A Critical Appraisal, p. 92. Eds. J. L. Pasteels, C. Robyn and F. J. G. Ebling. Excerpta Medica, Amsterdam.

BRyant, G.D. \& Stelmasiak, T. (1975) The specificity of a radioimmunoassay for relaxin. Endocr. Res. Commun. 1, 415-433.

Bryant, G.D., Stelmasiak, T., Chamley, W.A. \& Cumming, I.A. (1973) Sheep relaxin: application of a radioimmunoassay. Proc. 55th Meeting Endocr. Soc. Abstr. No. 258.

ChinAl, H.J. \& EsPEy, L.L. (1973) Utilization of the relaxed symphysis pubis of guinea-pigs for clues to the mechanism of ovulation. Endocrinology 93, 1441-1445.

Cumming, I.A., Brown, J.M., Goding, J.R., Bryant, G.D. \& Greenwood, F.C. (1972) Secretion of prolactin and luteinizing hormone at oestrus in the ewe. F. Endocr. 54, 207-213.

Feli, L.R., Beck, C., Brown, J.M., CAtT, K.J., Cumming, I.A. \& Goding, J.R. (1972) Solid-phase radioimmunoassay of ovine prolactin in antibody-coated tubes. Prolactin secretion during estradiol treatment, at parturition and during milking. Endocrinology 91, 1329-1336.

Goding, J.R., Catt, K.J., Brown, J.M., Kaltenbach, C.C., Cumming, I.A. \& Mole, B.J. (1969) Radioimmunoassay for ovine luteinizing hormone. Secretion of luteinizing hormone during estrus and following estrogen administration in the sheep. Endocrinology 85, 133-142.

Goding, J.R., Buckmaster, J.M., Cerrini, J.G., Cerini, M.E.D., Chamley, W.A., Cumming, I.A., FELL, L.R., FindLAY, J.K. \& Jonas, H.A. (1973) Gonadotrophins in the ovine oestrous cycle. $\mathcal{F}$. Reprod. Fert., Suppl. 18, 31-37.

McNatty, K.P., Revfeim, K.J.A. \& Young, A. (1973) Peripheral plasma progesterone concentrations in sheep during the oestrous cycle. F. Endocr. 58, 219-225.

Perd, E. \& Catchrole, H.R. (1950) Changes induced in the connective tissue of the pubic symphysis of the guinea-pig with estrogen and relaxin. Archs Pathol. 50, 235-239.

RADFORD, H.M., WATSON, R.H. \& WoOD, G.F. (1960) A crayon and associated harness for the detection of mating under field conditions. Aust. vet. 7. 36, 57-66.

Salamonsen, L.A., Jonas, H.A., Burger, H.G., Buckmaster, J.M., Chamley, W.A., Cumming, I.A., FindLAY, J.K. \& Goding, J.R. (1973) A heterologous radioimmunoassay for follicle stimulating hormone: application to measurement of FSH in the ovine estrous cycle and in several species including man. Endocrinology 93, 610-618.

Simpson, E.R., Jefrcoate, G.R., Collett, R.A. \& Land, R.B. (1973) Cytochrome P-450 activity in sheep corpora lutea during the oestrous cycle. F. Endocr. 58, 493-501.

Thorburn, G.D., Bassett, J.M. \& SMrth, I.D. (1969) Progesterone concentrations in the peripheral plasma of sheep during the oestrous cycle. 7 . Endocr. 45, 459-469.

Thorneycroft, I.A., Shribyatta, B., Tom, W.K., Nakamura, R.M. \& Mishrll, D.R. (1974) Measurement of serum LH, FSH, progesterone, 17-hydroxyprogesterone and estradiol-17 $\beta$ levels at 4 hour intervals during the periovulatory phase of the menstrual cycle. F. clin. Endocr. Metab. 39, 754-758. 